\title{
Assessment of the Impact of Hydraulic Binder on the Properties of the Cold Recycled Mixture with Foamed Bitumen and Bitumen Emulsion: Field Tests
}

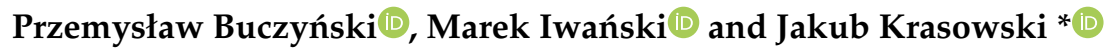 \\ Department of Transportation Engineering, Faculty of Civil Engineering and Architecture, \\ Kielce University of Technology, Al. Tysiąclecia Państwa Polskiego 7, 25-314 Kielce, Poland; \\ p.buczynski@tu.kielce.pl (P.B.); iwanski@tu.kielce.pl (M.I.) \\ * Correspondence: jkrasowski@tu.kielce.pl; Tel.: +48-413-424-560
}

Received: 5 October 2020; Accepted: 26 November 2020; Published: 30 November 2020

check for updates

\begin{abstract}
The paper presents the results of tests of the impact of hydraulic and bituminous binders on the properties of the cold-recycled mixture (CRM). The composition of the cold-recycled mixture includes two types of different binders, i.e., bituminous binder in the form of foamed bitumen and bitumen emulsion, as well as Portland cement (CEM I 32.5R) and hydraulic binder. The hydraulic binder was produced by mixing three base ingredients in the following ratio: 40\% CEM I 32.5R; $20 \% \mathrm{Ca}(\mathrm{OH})_{2}$ and $40 \% \mathrm{CBD}$ (cement bypass dust). The cold-recycled mixtures were produced under industrial conditions on a test section. The prepared CRM with bitumen emulsion (MCE) and foamed bitumen (MCAS) was collected from the test section and compacted under laboratory conditions. The impact of the type and kind of the binder was assessed in terms of physical properties, mechanical properties and deformation modulus (bearing capacity of subbase) of the recycled base course after 1 , 7 and 28 days. It was found that the use of hydraulic binder in the recycled base course, regardless of the type of bituminous binder, reduced cohesion without reducing the remaining parameters.
\end{abstract}

Keywords: foamed bitumen; bitumen emulsion; cold-recycled mixture; hydraulic binder; durability

\section{Introduction}

Global environmental policy contributes to the development and use of technologies that ensure the smallest possible energy consumption, reduced pollution and less environmental degradation [1]. Many industry branches generate significant pollution due to the overproduction of by-products [2]. Such processes include, for instance, the construction of roads, which involves many types of works related to the demolitibnbon of damaged pavements. Waste reduction is achieved through the use of recycling technologies [3,4]. Common methods employed to re-use waste materials include deep cold recycling with foamed bitumen [5] (MCAS) and bitumen emulsion (MCE) [6,7].

The cold recycling technology assumes the construction of the road base with the use of materials from the demolition of old pavement structures. The process takes place at ambient temperature. Shredded materials from the waste in the form of a reclaim, are mixed with the addition of asphalt emulsion or foamed asphalt and a hydraulic binder. As a result, a new, load-bearing capacity of subbase is created while minimizing losses incurred for the purchase of new materials, transport and disposal of old ones. The entire process brings environmental benefits related to the reduction of production, emission of pollutants and energy consumption. Reconstruction of the roadway made in this technology allows for a quick improvement of operational parameters $[8,9]$.

The subbase made of the recycled cold mix can be manufactured in two ways, in the factory "In-plant" or on-site, i.e., "in-place" [9]. To produce the mixture on-site, specialized recyclers are 
used, which enable the mixing of individual materials, including the old surface layers that have been crushed earlier. An exemplary in-place recycling facility is shown in Figure 1.

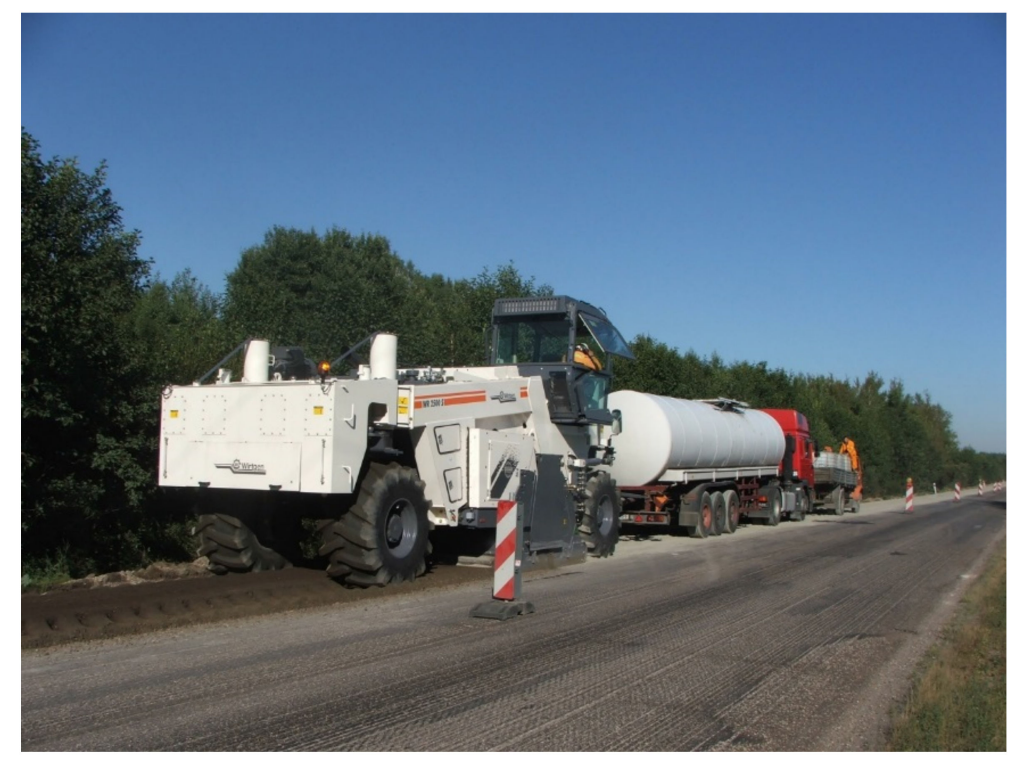

Figure 1. Manufacturing of the bitumen emulsion (MCE) mixture using the "in-place" method. [J. Krasowski].

At the beginning of the process, the seeder spreads the hydraulic road binder, which may be, e.g., cement, and the well-graded aggregate is subsequently distributed. The recycler, linked by a rigid line with a water cistern, and a cistern containing bitumen or slow decomposition emulsion, mix all the components of the new foundation. The emulsion is pumped straight into the drum. In the case of foamed bitumen, it is formed when the hot bitumen and water come into contact. Both materials are forced with special nozzles into the drum chamber. Cold water, due to contact with hot road asphalt, evaporates rapidly, causing bitumen foam. The binder coats the mineral particles of aggregate with the addition of cement, ultimately providing excellent material for the foundation. After passing the recycler, it is necessary to pre-compact with a steel-rubber roller, because the material is significantly loosened. Another device that is involved in the process is a grader that profiles a new foundation to a specific shape. This is followed by the proper compaction of the layer, using a steel-rubber roller with a smooth drum and a rubber-pneumatic roller, which compacts the whole [10].

The second option is to make the foundation using delivered material, that is, transported to the section, from a special factory. A mixture of recycled materials, produced in cold technology in the factory, is placed on a properly prepared substrate. Here, the reclaimed material (with corrected grain size) is mixed with the binder. The advantage of this technology is greater accuracy of dosing ingredients and control of produced material composition. The prepared mixture is transported by self-unloading cars. It is placed along the length using a grader or paver. Next, the new foundation is thoroughly compacted with a set of road rollers. The entire procedure is controlled both by tests on the building site and in the laboratory. The foundation made this way can be covered with an appropriate package of bituminous layers, depending on the traffic load category. An exemplary in-plant recycling facility is shown in Figure 2. 


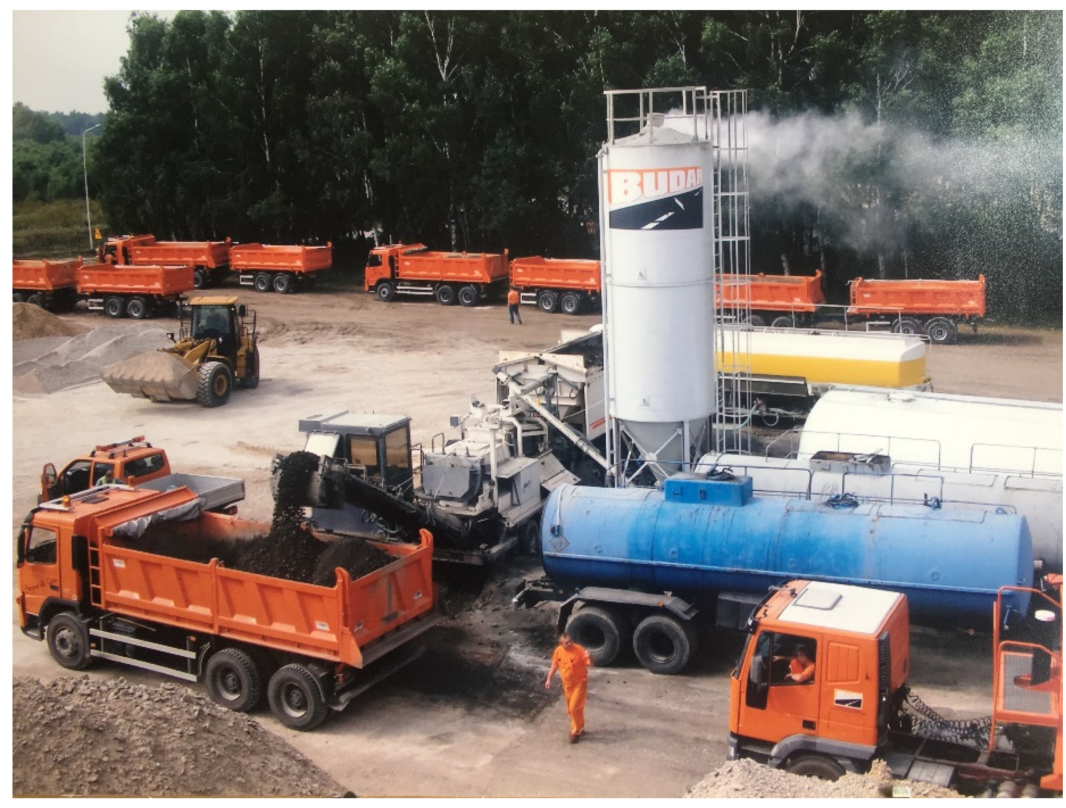

Figure 2. Performing of the MCE mixture using the "in-place" method. [J. Krasowski].

Studies have shown that the use of Portland cement in the recycled mixture results in an excessive increase in stiffness [6], causing the base course to crack due to over-stiffening [11]. That is why it seems necessary to look for a binder other than Portland cement that will ensure the primary physical and mechanical properties, reduce stiffness, and guarantee a long service life of the recycled base course.

\section{Subject of the Test}

The subject of the tests is the cold-recycled mixture (CRM). The tests concerned the assessment of the impact of binder type on the properties of the cold-recycled mixture containing two types of binders, i.e., foamed bitumen and bitumen emulsion, as well as Portland cement (CEM I 32.5R) and hydraulic binder. Foamed bitumen and bitumen emulsion were produced from 70/100 penetration grade bitumen for roads. The hydraulic binder was produced by mixing three base ingredients in the following ratio: $40 \%$ CEM I 32.5R; $20 \% \mathrm{Ca}(\mathrm{OH})_{2}$ and $40 \% \mathrm{CBD}$ (cement bypass dust). Binders for the test section were prepared on an industrial scale. The recycled mixture was prepared under industrial conditions using the "in situ" method [9]. The base course layer is dedicated to traffic volume category KR3-4 $\left(0.50<\right.$ ESAL $_{100} \leq 7.30$ million standard 100-kN axles) [12].

The test section was located at an open-pit mine in Świętokrzyskie Province. This location makes it possible to fairly quickly determine the behaviour of the recycled base course with foamed bitumen and bitumen emulsion and with the dedicated binder under high-stress conditions.

The test section was divided into four parts; a diagram and division of the section are shown in Figure 3. The equipment used to prepare the recycled base course under industrial conditions using the "in situ" method is shown in Figure 4. 


\begin{tabular}{|c|c|}
\hline \multicolumn{2}{|c|}{$\mathrm{Km} 0+200$} \\
\hline $\begin{array}{c}\text { Part } 4 \\
\text { MCAS + "5C" } \\
\text { Area: } 300 \mathrm{~m}^{2}\end{array}$ & $\begin{array}{c}\text { Part } 2 \\
\text { MCAS + CEM } \\
\text { Area: } 300 \mathrm{~m}^{2}\end{array}$ \\
\hline \multicolumn{2}{|c|}{$\mathrm{Km} 0+100$} \\
\hline $\begin{array}{c}\text { Part } 3 \\
\text { MCE + “5C" } \\
\text { Area: } 300 \mathrm{~m}^{2}\end{array}$ & $\begin{array}{c}\text { Part } 1 \\
\text { MCE + CEM } \\
\text { Area: } 300 \mathrm{~m}^{2}\end{array}$ \\
\hline & \\
\hline
\end{tabular}

Figure 3. Diagram showing the division of the test section.

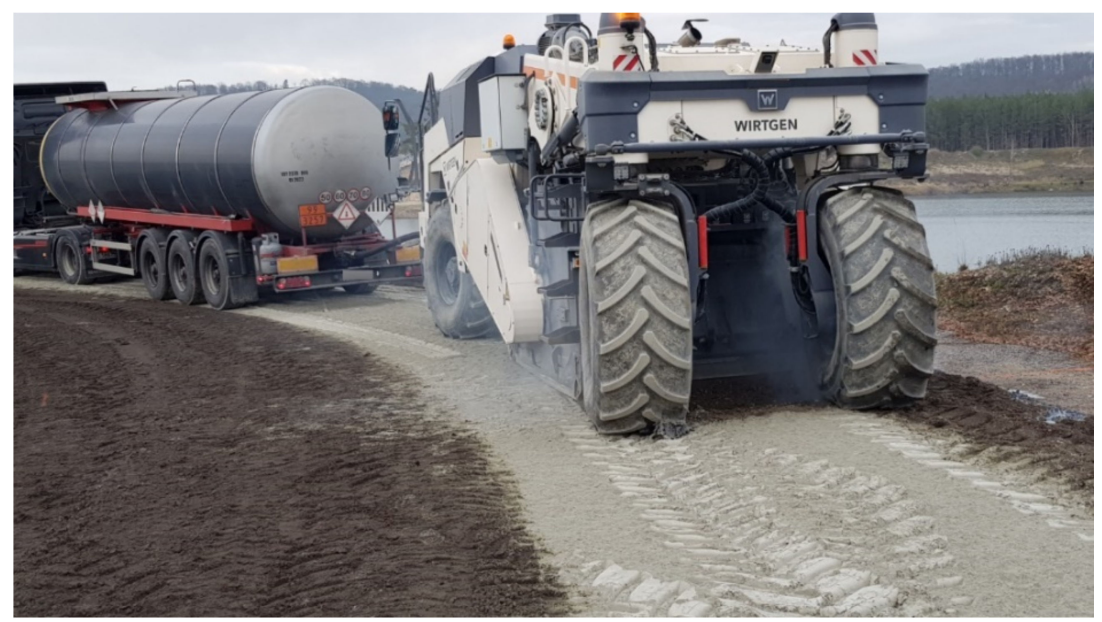

Figure 4. Preparation of the recycled mixture under field conditions using the "in situ" method [P. Buczyński].

This way, it will be possible to unambiguously assess the quality of the produced mixture and draw conclusions regarding the impact of the type and kind of the binders on the properties of the cold-recycled mixture.

\section{Materials and Methods}

\subsection{Binding Agents}

Bituminous binders included foamed bitumen and bitumen emulsion. Both foamed bitumen and bitumen emulsion were produced from 70/100 penetration grade bitumen for roads. Results of tests of the primary properties of the bitumen for roads are given in Table 1.

Table 1. Results of the tests of the properties of the 70/100 bituminous binder.

\begin{tabular}{ccccccc}
\hline Bitumen for Roads & \multicolumn{2}{c}{ Penetration $\mathbf{( 0 . 1} \mathbf{~ m m})$} & \multicolumn{2}{c}{$\mathrm{T}_{\text {PiK }}\left({ }^{\circ} \mathbf{C}\right)$} & \multicolumn{2}{c}{$\mathbf{T}_{\text {Fraass }}\left({ }^{\circ} \mathbf{C}\right)$} \\
\hline- & Average & SD & Average & SD & Average & SD \\
\hline $70 / 100$ & 75.80 & 2.15 & 45.2 & 0.03 & -17.9 & 0.55 \\
\hline
\end{tabular}


The bitumen foaming characteristic was determined for foamed bitumen regarding the following parameters: expansion ratio (ER) and half-life (HL) in accordance with [5]. The results are shown in Figure 5.

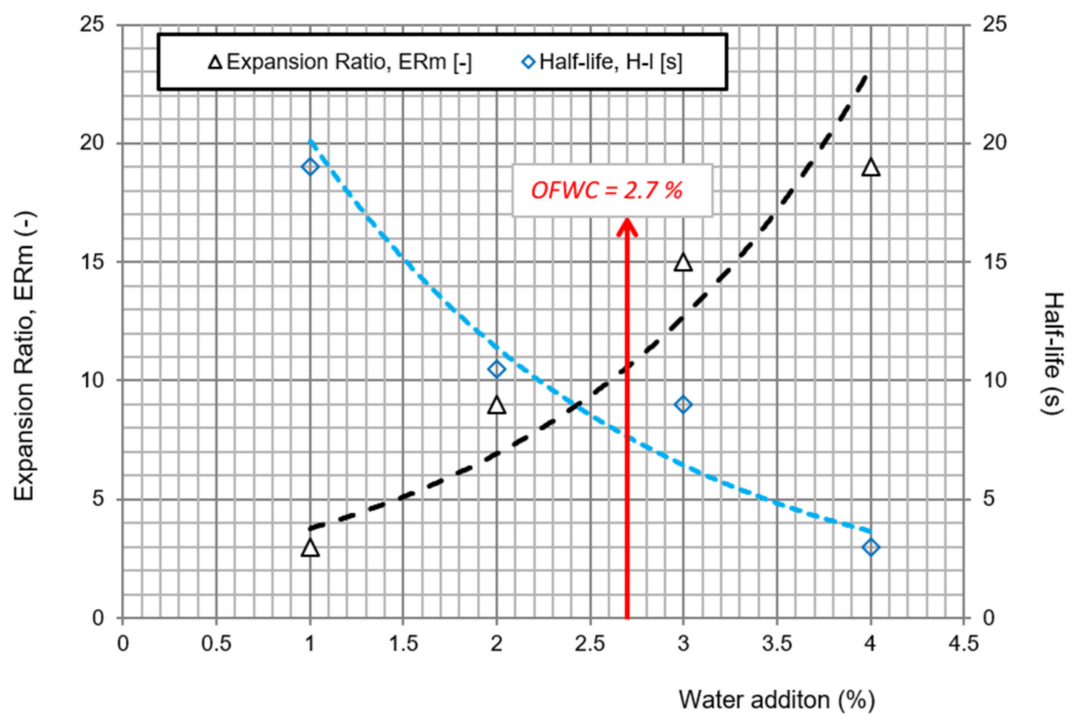

Figure 5. Determination of the optimum foaming water content for 70/100 bitumen.

$\mathrm{T}_{\mathrm{PiK}}$ is the basic parameter defining the properties of asphalt in the so-called high operating temperature. It constitutes the upper limit of the visco-elastic state of the binder [13].

$\mathrm{T}_{\text {Fraass }}$ determines the low-temperature properties of the asphalt and, approximately, the lower limit of the visco-elastic state [14].

Expansion ratio (ER) is a parameter that shows how much the volume of the starting (liquid) asphalt has increased after it has been exposed to water [9].

Half-life (HL) is the half-life, i.e., the time of bursting of asphalt foam bubbles. This parameter shows how long the foamed bitumen goes from its maximum volume to its half. It is advisable that the time is as long as possible so that, in the technological recycling process, the ingredients of the mixture should be covered with asphalt foam in the best and most effective manner [9].

The quality of the $\mathrm{C} 60 \mathrm{~B} 10 \mathrm{ZM} / \mathrm{R}$ bitumen emulsion was assessed in the context of the requirements of the national annex to the harmonised standard [15]. The results are given in Table 2.

Table 2. Physical properties of asphalt emulsions.

\begin{tabular}{ccc}
\hline Component & Units & $\begin{array}{c}\text { Bitumen } \\
\text { Emulsion-C60B10 ZM/R }\end{array}$ \\
\hline Binder content & $\%(\mathrm{~m} / \mathrm{m})$ & 60 \\
Mixing stability with cement & $\mathrm{g}$ & 1.0 \\
0.5 mm sieve residue & $\%(\mathrm{~m} / \mathrm{m})$ & 0.04 \\
Efflux time $\varnothing 2 \mathrm{~mm}$ at $40{ }^{\circ} \mathrm{C}$ & $\mathrm{s}$ & 32 \\
Adhesion to aggregate & $\%$ & 85 \\
\hline
\end{tabular}

The properties of the hydraulic binders used in the recycled mixtures are presented in Table $3[2,16]$. 
Table 3. Properties of Portland cement and hydraulic road binder " $5 \mathrm{C}$ ".

\begin{tabular}{ccccc}
\hline Property & Test & Units & CEM I 32.5R & HRB* “5C” \\
\hline Initial setting time & EN 196-3 [17] & $\min$ & 200 & 265 \\
Final setting time & & $\min$ & 265 & 460 \\
Compressive strength at 7 days & EN 196-1 [18] & $\mathrm{MPa}$ & 34.2 & 7.7 \\
Compressive strength at 28 days & $\mathrm{MPa}$ & 46.8 & 13.6 \\
Volume constancy & EN 196-3 [17] & $\mathrm{mm}$ & 9 & 17 \\
Specific surface area & EN 196-6 [19] & $\mathrm{cm}^{2} / \mathrm{g}$ & 4282 & 5010 \\
\hline
\end{tabular}

*-Hydraulic Road Binder.

The hydraulic road binder ( $\mathrm{HRB}$ " $5 \mathrm{C}$ ") was produced by mixing three base ingredients in the following ratio: $40 \%$ CEM I $32.5 \mathrm{R} ; 20 \% \mathrm{Ca}(\mathrm{OH})_{2}$ and $40 \% \mathrm{CBD}$ (cement bypass dust). The results of the tests of the binder components are presented in detail in the article [20].

\subsection{Aggregate}

In accordance with the recommendations [8,9], the cold-recycled mixture has to include material from an existing system of structural layers. That is why the cold-recycled mixtures included $0 / 31.5 \mathrm{~mm}$ reclaimed asphalt pavement (RAP) produced by milling existing layers made from asphalt mixtures and natural 0/31.5 continuously graded crushed-stone aggregate from an existing base course. The bitumen content in reclaimed asphalt pavement (RAP) was $5.1 \%$, and it was determined in accordance with the requirements of [21].

\subsection{Mix Design of the Cold-Recycled Mixture}

The laboratory mix design of the cold-recycled mixture was prepared in accordance with the guidelines for the MCAS mixture [8,9] and MCE mixture [22]. The composition of the recycled mixture was selected in such a way as to meet the gradation criterion for the recycled mixture with both foamed bitumen and bitumen emulsion. The gradation curve is shown in Figure 6.

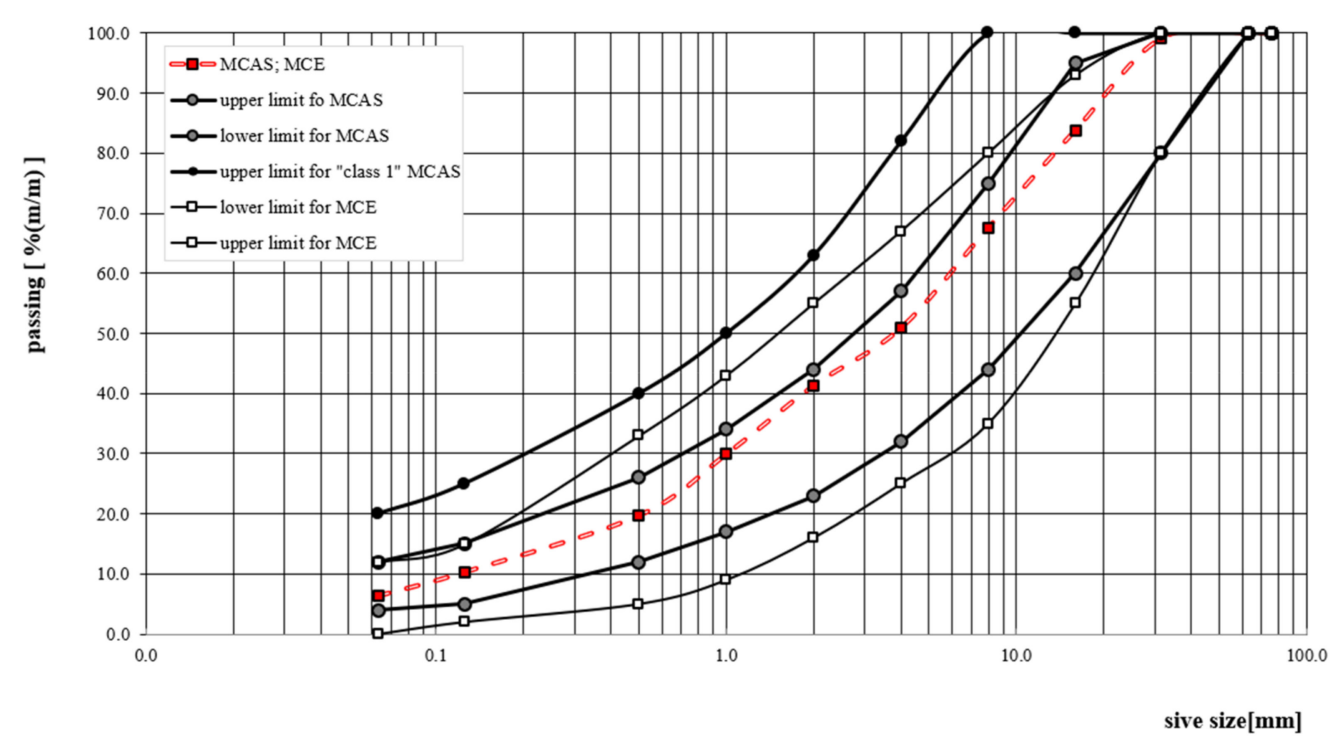

Figure 6. Gradation curve of the foamed bitumen (MCAS)/MCE cold-recycled mixture.

The designed mineral mix conforms to the gradation criterion for both of the analysed deep recycling methods. The percentage share of mineral ingredients, hydraulic binders and bituminous binders used in the cold-recycled mixtures produced using the different methods is given in Table 4 . 
Table 4. Composition of the MCAS/MCE cold-recycled mixture.

\begin{tabular}{|c|c|c|c|c|c|}
\hline \multirow{2}{*}{ Component } & \multirow{2}{*}{$\begin{array}{c}\text { Density } \\
\rho_{\mathrm{a}} \\
\left(\mathrm{kg} / \mathrm{m}^{3}\right)\end{array}$} & \multicolumn{4}{|c|}{ Share $(\%)$ of Ingredients } \\
\hline & & MCAS-CEM & MCAS-“5C” & MCE-CEM & MCE-“5C" \\
\hline $\begin{array}{l}\text { Reclaimed asphalt pavement } \\
\text { (RAP \# } 31.5 \mathrm{~mm} \text { ) }\end{array}$ & 2547 & 37.6 & 37.6 & 37.6 & 37.6 \\
\hline $0 / 31.5 \mathrm{~mm}$ natural aggregate & 2661 & 56.4 & 56.4 & 56.4 & 56.4 \\
\hline CEM I 32.5R Portland cement & 3010 & 3.0 & 3.0 & 3.0 & - \\
\hline$" 5 C "$ hydraulic binder & 2860 & - & 3.0 & - & 3.0 \\
\hline $50 / 70$ foamed bitumen & 1020 & 3.0 & - & - & - \\
\hline $\begin{array}{c}\text { C60B10 ZM/R bitumen } \\
\text { emulsion * }\end{array}$ & 1010 & - & - & $3.0 *$ & $3.0^{*}$ \\
\hline
\end{tabular}

*-the amount of $\mathrm{C} 60 \mathrm{~B} 10 \mathrm{ZM} / \mathrm{R}$ bitumen emulsion was dosed as $5.0 \%$; the amount of bitumen precipitated from the bitumen emulsion was $3.0 \%$.

\subsection{Methodology}

The impact of the hydraulic binder and bituminous binder on the properties of the cold-recycled mixture was assessed in the context of physical and mechanical properties as well as the strength of the base course in the field.

In order to assess the physical and mechanical properties, the mixture was produced under field conditions at the test section and compacted under laboratory conditions. The samples were compacted using a static press in accordance with the requirements indicated in instructions [8]. This method was used in such a way as to reflect the compactive effort specified in the Marshall method [22,23]. The cold-recycled mixture was assessed in terms of the following: density $\left(\rho_{m c}\right)$ [24], dry bulk density $\left(\rho_{b d r y}\right)$ [25], indirect tensile strength after 7 days at $+5{ }^{\circ} \mathrm{C}$ (ITS DRY) [26] and uniaxial compressive strength (UCS) [27].

The strength of the base course was assessed by evaluating the deformation modulus determined by plate loading in accordance with the requirements $[28,29]$. Strength changes were analysed at intervals of 1,7 and 28 days after the construction of the base course.

\subsubsection{Density}

The density of the mixtures $\left(\rho_{m c}\right)$ is determined in the laboratory, in accordance with the guidelines contained [24]. The density is determined as w Equation (1):

$$
\rho_{m c}=\frac{m_{2}-m_{1}}{1000 \times V_{p}-\left(m_{3}-m_{2}\right) / \rho_{w}}
$$

where $\rho_{m c}$ is density in megagram per cubic meter $\left(\mathrm{Mg} / \mathrm{m}^{3}\right) ; m_{1}$ is mass of the pycnometer with cap, expressed in grams (g); $m_{2}$ mass of the pycnometer with the cap and the test sample, expressed in grams $(\mathrm{g}) ; m_{3}$ is mass of the pycnometer with the cap, the test sample and water or solvent, expressed in grams $(\mathrm{g}) ; V_{p}$ volume of the piconometer filled to the measuring mark, expressed in cubic meter $\left(\mathrm{m}^{3}\right)$ and $\rho_{w}$ is the density of water at the test temperature in megagram per cubic meter $\left(\mathrm{Mg} / \mathrm{m}^{3}\right)$.

\subsubsection{Dry Bulk Density}

Dry bulk density is determined as mass per unit volume, including air voids, of a specimen at known test temperature [25]. Dry bulk density (SSD) of the specimen $\left(\rho_{b d r y}\right)$ should be calculated to the nearest $0.001 \mathrm{Mg} / \mathrm{m}^{3}$ as Equation (2):

$$
\rho_{b d r y}=\frac{m_{1}}{m_{3}-m_{2}} \times \rho_{w}
$$

where $\rho_{b d r y}$ is bulk density (SSD) in megagram per cubic meter $\left(\mathrm{Mg} / \mathrm{m}^{3}\right) ; m_{1}$ is the mass of the dry specimen in grams $(\mathrm{g}) ; m_{2}$ is the mass of the specimen in water, expressed in grams $(\mathrm{g}) ; m_{3}$ is the mass 
of the saturated dry surface of the specimen, expressed in grams (g); and $\rho_{w}$ is the density of water at the test temperature in megagram per cubic meter $\left(\mathrm{Mg} / \mathrm{m}^{3}\right)$.

\subsubsection{Indirect Tensile Strength ( ITS $\left._{\mathrm{DRY}}\right)$}

The ITS $\mathrm{DRY}_{\mathrm{D} Y}$ test [26] of the cement-bound mixture was performed on Marshall specimens with a diameter of $101.6 \pm 0.3 \mathrm{~mm}$ and a height of $62.5 \pm 2.5 \mathrm{~mm}$ cured for 28 days at a relative humidity of $40-70 \%$ and test temperature of $+25{ }^{\circ} \mathrm{C}$. The tensile characteristics were evaluated by placing the specimen between two loading strips and applying a compressive load at a constant deformation rate of $50 \pm 2 \mathrm{~mm} / \mathrm{min}$. The indirect tensile strength ITS is calculated from Equation (3):

$$
\mathrm{ITS}_{\mathrm{DRY}}=\frac{2 \times P}{\pi \times h \times D}
$$

where $P$ is the maximum load at failure, $h$ is the specimen height, $(\mathrm{mm})$ and $D$ is plate diameter, $(\mathrm{mm})$.

\subsubsection{Compressive Strength}

Axial compressive strength $\left(R_{C}\right)$ was determined on cylindrical specimens prepared with the Proctor method following the requirements of EN 13286-50 [30]. The test temperature was $25 \pm 3{ }^{\circ} \mathrm{C}$ as per PN-EN 13286-41 [27]. The 28-day compressive strength was determined from Equation (4):

$$
R_{C}=\frac{F}{A_{C}}
$$

where $R_{C}$ is the compressive strength of cement bound specimens (MPa), $F$ is the maximum transferred force $(\mathrm{N})$, and $A_{C}$ is the cross-sectional area of the cement bound specimen $\left(\mathrm{mm}^{2}\right)$.

\subsubsection{Deformation Modulus}

The deformation modulus $[28,29]$ was described as the product of the ratio of unit load (between 0.25 MPa and $0.35 \mathrm{MPa}$ ) to the strain rate in the tested layer within the specified unit load range, in accordance with Equation (5):

$$
E_{1,2}=\frac{3 \times \Delta p}{4 \times \Delta s} \times D
$$

where $\Delta p$ is pressure increase, [MPa]; $\Delta s$ is displacement increase rate corresponding to the pressure increase, $(\mathrm{mm})$ and $D$ is a plate diameter, $(\mathrm{mm})$.

The test consists of measuring vertical deformations of the tested substrate layer under the influence of static pressure induced by a steel round plate with a diameter of $D=300 \mathrm{~mm}$. The pressure on the plate is evoked by a hydraulic jack. The jack is based on a counterweight, the mass of which should exceed the force applied.

\section{Results and Discussion}

\subsection{Physical and Mechanical Properties}

The mean value for each analyzed parameter was determined with 3 replications. The samples of the cold-recycled mixture were prepared as described in Section 3.3. The mean values, standard deviation and coefficient of variation for the physical properties determined in accordance with the plan of the tests are given in Table 5. 
Table 5. Results of tests of physical properties of the MCAS/MCE cold-recycled mixture.

\begin{tabular}{cccccccccc}
\hline \multirow{2}{*}{ Mixture } & \multicolumn{3}{c}{$\rho_{\text {mv }}\left(\mathbf{k g} / \mathbf{m}^{\mathbf{3}}\right)$} & \multicolumn{3}{c}{$\rho_{\text {bdry }}\left(\mathbf{k g} / \mathbf{m}^{\mathbf{3}}\right)$} & \multicolumn{3}{c}{$\mathbf{V}_{\mathbf{m}}(\mathbf{\%})$} \\
\cline { 2 - 10 } & $\mathbf{X}$ & $\mathbf{s}$ & $\boldsymbol{v}(\mathbf{\%})$ & $\mathbf{X}$ & $\mathbf{s}$ & $\boldsymbol{v}(\mathbf{\%})$ & $\mathbf{X}$ & $\mathbf{s}$ & $\boldsymbol{v}(\%)$ \\
\hline MCAS + CEM & 2428 & 9.0 & 0.4 & 2139 & 8.0 & 0.4 & 11.9 & 0.9 & 7.6 \\
MCAS + 5C & 2425 & 7.0 & 0.3 & 2161 & 7.0 & 0.3 & 10.9 & 1.0 & 8.8 \\
MCE + CEM & 2381 & 9.0 & 0.4 & 2127 & 8.0 & 0.4 & 10.7 & 0.8 & 7.1 \\
MCE + 5C & 2370 & 12.0 & 0.5 & 2136 & 13.0 & 0.6 & 9.9 & 0.6 & 6.1 \\
\hline
\end{tabular}

Descriptive statistics: $X$-mean value, $\mathrm{s}$-standard deviation of the sample, $\mathrm{v}$-coefficient of variation.

The results of the tests of the physical properties describe the internal structure of the cold-recycled mixture depending on its ingredients. The density $\left(\rho_{m v}\right)$ and dry bulk density $\left(\rho_{b d r y}\right)$ indicate that, irrespective of the type of hydraulic binder, the cold-recycled mixture with foamed bitumen (MCAS) achieves greater density that the mixture with bitumen emulsion (MCE). The density of the mixture with foamed bitumen is approx. $0.050 \mathrm{Mg} / \mathrm{m}^{3}$ higher, and the bulk density is approx. $0.020 \mathrm{Mg} / \mathrm{m}^{3}$ higher. This relationship is reversed in the case of air void content, which was slightly lower for the cold-recycled mixture with bitumen emulsion. The air void content (Table 5) indicates that all mixtures had been properly compacted, achieving the recommended air void content $[8,22]$. The indirect tensile strength (ITS) and uniaxial compressive strength (UCS) are used to assess the quality of cold-recycled mixtures $[8,22]$. The indirect tensile strength (ITS) was determined at $+5^{\circ} \mathrm{C}$ in accordance with the recommendations for the MCE mixture [22], and the uniaxial compressive strength was determined at $+25{ }^{\circ} \mathrm{C}$ [8]. The results of tests of indirect tensile strength are shown in Figure 7, and the changes of uniaxial compressive strength (UCS) depending on conditioning time are shown in Figure 8.

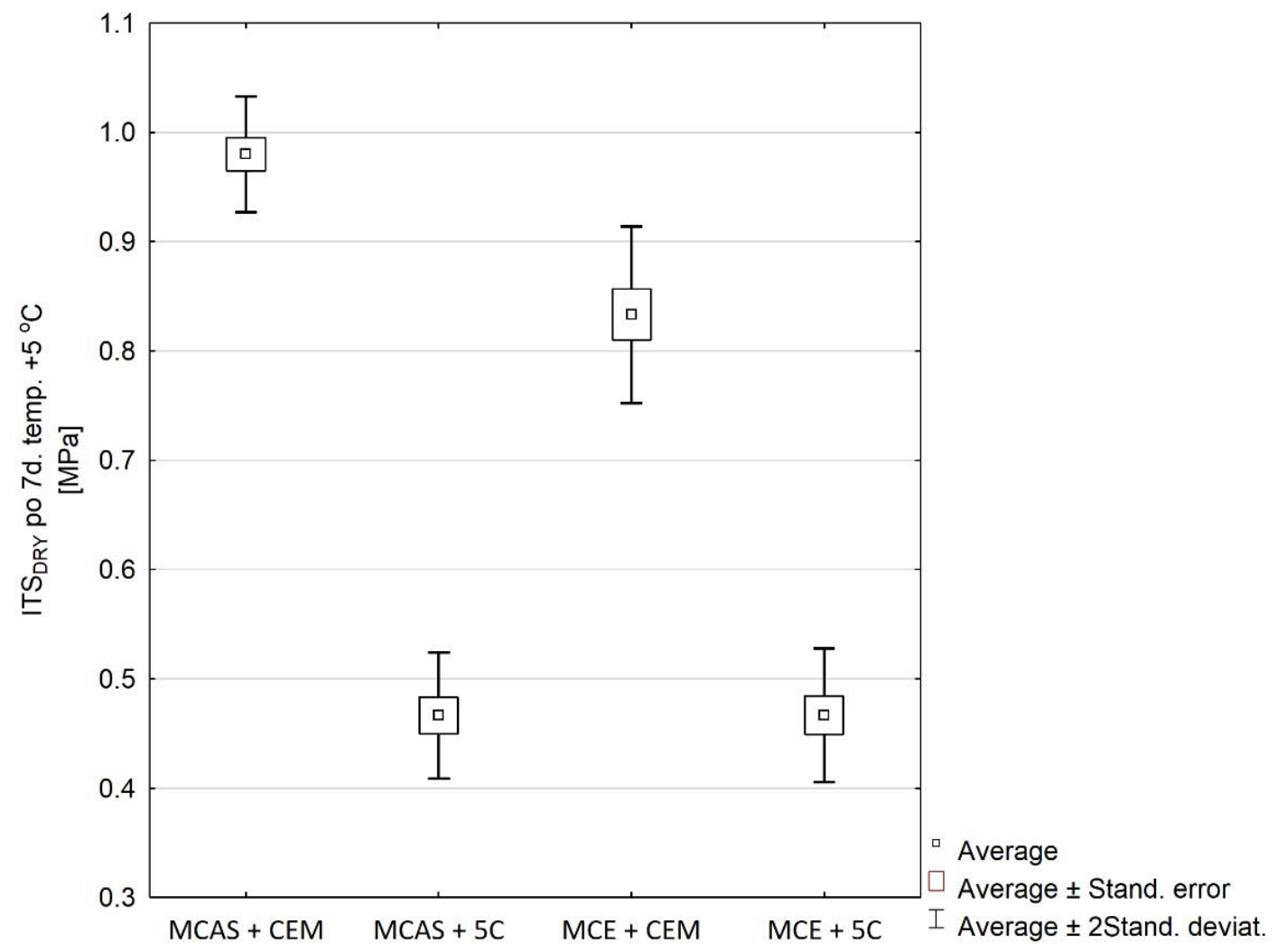

Figure 7. Indirect tensile strength for the MCAS/MCE cold-recycled mixture. 


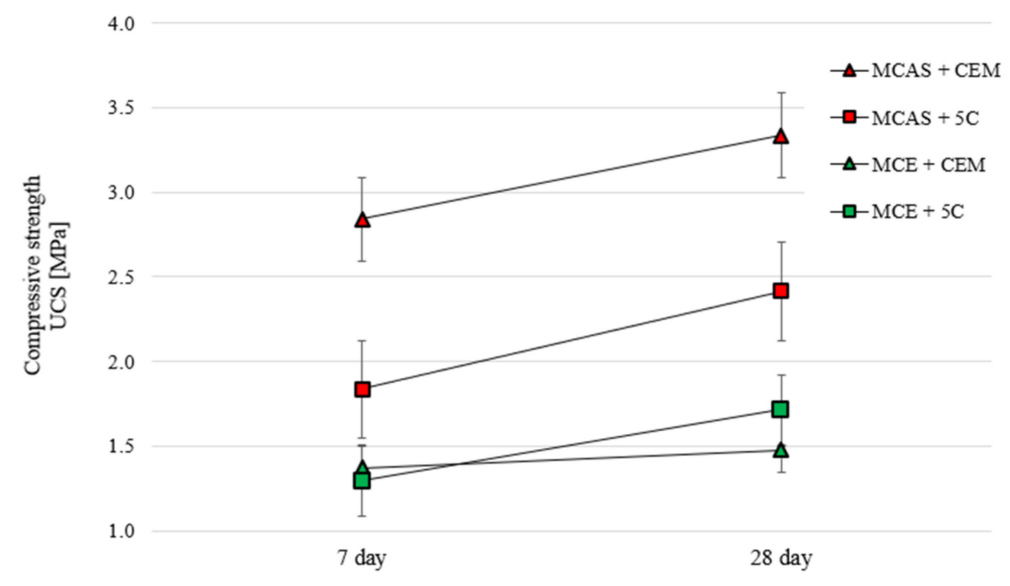

Figure 8. Compressive strength for the cold-recycled mixture (error bars represent standard error).

Regardless of the type of bituminous binder, the indirect tensile strength (ITS) was higher for the base course with Portland cement. The indirect tensile strength (ITS) of the cold-recycled mixture containing Portland cement was almost two times higher. This relationship is related to the composition of the hydraulic binder. CEM I 32.5R Portland cement is one of the three ingredients of the " $5 \mathrm{C}$ " hydraulic binder, and it makes up only $40 \%$ of the mass. It should also be noted that the indirect tensile strength was similar irrespective of the type of the bituminous binder, but it varied depending on the type of the hydraulic binder.

Unlike what was observed with respect to the indirect tensile strength, the uniaxial compressive strength (Figure 8) varied depending on the type of the bituminous binder and hydraulic binder. The cold-recycled mixture with foamed bitumen (MCAS) clearly has the highest uniaxial compressive strength (UCS).

\subsection{Assessment of the Deformation Modulus of the Recycled Base Course}

The strength of the base course constructed from the cold-recycled mixture was assessed by evaluating the deformation modulus determined by plate loading in accordance with the requirements $[28,29]$. Strength changes were analysed at intervals of 1,7 and 28 days after the construction of the base course. The manufacturing process is described in Section 3.4.5.

The set-up used to test the deformation modulus is shown in Figure 9.

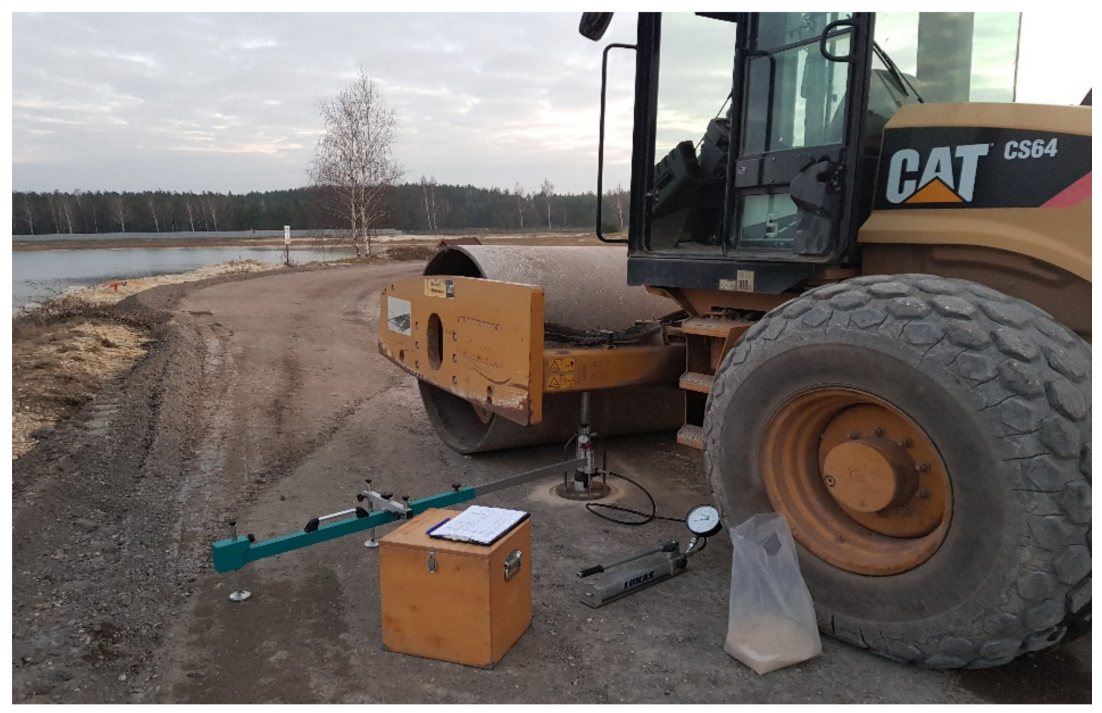

Figure 9. Measurement of base course bearing capacity in the field (J. Krasowski). 
The tests determined the initial loading modulus $\left(\mathrm{E}_{1}\right)$, reloading modulus $\left(\mathrm{E}_{2}\right)$ and modulus ratio $\mathrm{I}_{\mathrm{O}}$. The modulus ratio $\left(\mathrm{I}_{\mathrm{O}}\right)$ represents the compaction of the layers, and it is described by the ratio of the reloading modulus $\left(\mathrm{E}_{2}\right)$ to the initial loading modulus $\left(\mathrm{E}_{1}\right)$. If the modulus ratio is lower than 2.2, this indicates that the layer has been compacted correctly. The test results are given in Figure 10.

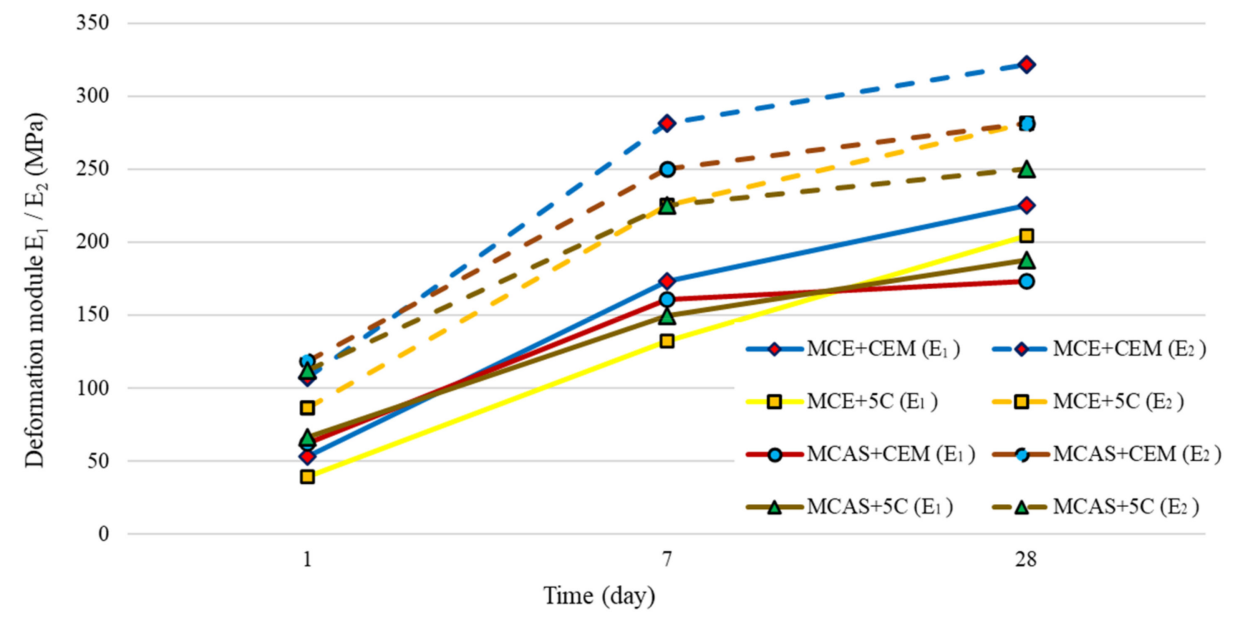

Figure 10. Results of tests of the strength of the recycled base course.

The curing time for the recycled base course contributes to the increase in strength (Figure 10) described by the deformation modulus. The increase in strength between the 1 st and 28 th day after the construction of the base course is 3.0 on average. The modulus ratio $\mathrm{I}_{\mathrm{O}}$ indicates that the recycled mixture was compacted correctly $\left(\mathrm{I}_{\mathrm{o}}<2.2\right)$. In most cases, the initial strength, after 1 day of curing, was higher than $100 \mathrm{MPa}$. Only the recycled base course with bitumen emulsion containing the " $5 \mathrm{C}$ " hydraulic binder had deformation modulus $\mathrm{E}_{2}=86.5 \mathrm{MPa}$. Irrespective of the type of the bituminous binder, the highest strength was achieved by the base courses with Portland cement. The analysed results indicate that the minimum required strength for $\mathrm{MCE}_{2} \geq 180 \mathrm{MPa}$ and for $\mathrm{MCAS} \mathrm{E}_{2} \geq 150 \mathrm{MPa}$ could be achieved after approx. 3 days of the curing of the layer.

\section{Conclusions}

The tests of the impact of the type of the binder on the properties of the cold-recycled mixture support the following conclusions:

- $\quad$ The density $\left(\rho_{m c}\right)$ and dry bulk density $\left(\rho_{b d r y}\right)$ indicate that, irrespective of the type of hydraulic binder, the cold-recycled mixture with foamed bitumen (MCAS) achieves greater density that the mixture with bitumen emulsion (MCE). The density of the mixture with foamed bitumen is approx. $0.050 \mathrm{Mg} / \mathrm{m}^{3}$ higher, and the dry bulk density is approx. $0.020 \mathrm{Mg} / \mathrm{m}^{3}$ higher.

- The air void content was slightly lower for the cold-recycled mixture with bitumen emulsion (MCE). The average air void content $\left(\mathrm{V}_{\mathrm{m}}\right)$ was approximately $11.0 \%$.

- Irrespective of the type of bituminous binder, lower indirect tensile strength (ITS) was achieved for the hydraulic binder produced by mixing " $5 C^{\prime}$. The indirect tensile strength (ITS) of the cold-recycled mixture containing Portland cement was almost two times higher.

- $\quad$ The minimum required strength for the cold-recycled mixture with foamed bitumen (MCAS) and bitumen emulsion (MCE) could be achieved after approx. 3 days of curing of the layer.

- It is possible to obtain the required load-bearing capacity of the subbase with a hydraulic binder of much lower strength parameters. 
Author Contributions: Conceptualization, P.B., and M.I.; Methodology, P.B., M.I., and J.K.; Formal Analysis, P.B., M.I., and J.K.; Investigation, P.B. and J.K.; Resources, M.I.; Writing-Original Draft Preparation, P.B.; Writing-Review and Editing, M.I., J.K.; Visualization, P.B.; Supervision, P.B. and M.I.; Project Administration, M.I.; and Funding Acquisition, M.I. All authors have read and agreed to the published version of the manuscript.

Funding: The research results were developed as part of the project entitled "The innovative technology used the binding agent optimization that provides the long service life of the recycled base course" (TECHMATSTRATEG1/349326/9/NCBR/2017) within the scientific undertaking of the Strategic Research and Development Program entitled "Modern Materials Technology" (TECHMATSTRATEG I), which is financed by the National Center for Research and Development (Poland).

Conflicts of Interest: The authors declare no conflict of interest.

\section{References}

1. Chomicz-Kowalska, A.; Maciejewski, K. Performance and viscoelastic assessment of high-recycle rate cold foamed bitumen mixtures produced with different penetration binders for rehabilitation of deteriorated pavements. J. Clean. Prod. 2020, 258, 120517. [CrossRef]

2. Czapik, P.; Zapała-Sławeta, J.; Owsiak, Z.; Stępień, P. Hydration of cement by-pass dust. Constr. Build. Mater. 2020, 231, 117139. [CrossRef]

3. Dołżycki, B. Polish experience with cold in-place recycling. IOP Conf. Ser. Mater. Sci. Eng. 2017, 236, 012089. [CrossRef]

4. Skotnicki, L.; Kuźniewski, J.; Szydlo, A. Stiffness Identification of Foamed Asphalt Mixtures with Cement, Evaluated in Laboratory and In Situ in Road Pavements. Materials 2020, 13, 1128. [CrossRef] [PubMed]

5. Iwański, M.; Mazurek, G.; Buczyński, P. Bitumen Foaming Optimisation Process on the Basis of Rheological Properties. Materials 2018, 11, 1854. [CrossRef] [PubMed]

6. Niazi, Y.; Jalili, M. Effect of Portland cement and lime additives on properties of cold in-place recycled mixtures with asphalt emulsion. Constr. Build. Mater. 2009, 23, 1338-1343. [CrossRef]

7. Kukiełka, J.; Bańkowski, W. The experimental study of mineral-cement-emulsion mixtures with rubber powder addition. Constr. Build. Mater. 2019, 226, 759-766. [CrossRef]

8. Asphalt Academy Technical Guideline TG2: Bitumen Stabilised Materials. A Guideline for the Design and Construction of Bitumen Emulsion and Foamed Bitumen Stabilised Materials, 2nd ed.; Asphalt Academy: Pretoria, South Africa, 2009; Available online: http://www.aapaq.org/q/2011st/docs/TG2.pdf (accessed on 28 November 2020).

9. Wirtgen. Cold Recycling Technology, 1st ed.; Wirtgen GmbH: Windhagen, Germany, 2012; Available online: https://www.wirtgen.de (accessed on 28 November 2020).

10. Piłat, J.; Radziszewski, P. Nawierzchnie Asfaltowe: Podręcznik Akademicki; Wydawnictwa Komunikacji i Łączności: Warszawa, Poland, 2010; ISBN 978-83-206-1759-7.

11. Mazurek, G.; Iwanski, M. Optimisation of the innovative hydraulic binder composition for its versatile use in recycled road base layer. IOP Conf. Ser. Mater. Sci. Eng. 2019, 603, 032044. [CrossRef]

12. Katalog Typowych Konstrukcji Nawierzchni Podatnych i Pótsztywnych; Generalna Dyrekcja Dróg Krajowych i Autostrad: Warszawa, Poland, 2014.

13. Bitumen and Bituminous Binders. Determination of the Softening Point. Ring and Ball Method; PN-EN 1427; Polish Standards Institution: Warszawa, Poland, 2015.

14. Bitumen and Bituminous Binders. Determination of the Fraass Breaking Point; PN-EN 12593; Polish Standards Institution: Warszawa, Poland, 2015.

15. Bitumen and Bituminous Binders_Framework for Specifying Cationic Bituminous Emulsions; PN-EN 13808; Polish Standards Institution: Warszawa, Poland, 2013.

16. Owsiak, Z.; Zapała-Sławeta, J.; Czapik, P. Optymalizacja składu środka wiążącego o uniwersalnym charakterze zastosowania w recyklowanych podbudowach. In Innovative Technology Using Binder Optimization Designed for Deep Cold Recycling of Pavement Construction Ensuring its Operational Durability; Raport 1/1/PŚk/2018; Kielce University of Technology: Kielce, Poland, 2018. (In Polish)

17. Methods of Testing Cement. Determination of Setting Times and Soundness; PN-EN 196-3; Polish Standards Institution: Warszawa, Poland, 2016.

18. Methods of Testing Cement. Determination of Strength; PN-EN 196-1; Polish Standards Institution: Warszawa, Poland, 2016. 
19. Methods of Testing Cement. Determination of Fineness; PN-EN 196-6; Polish Standards Institution: Warszawa, Poland, 2011.

20. Owsiak, Z.; Czapik, P. Testing the cement, hydrated lime and cement by-pass dust mixtures hydration. Roads Bridg. Drogi Mosty 2020, 135-147. [CrossRef]

21. Bituminous Mixtures. Test Methods for Hot Mix Asphalt. Soluble Binder Content; PN-EN 12697-1; Polish Standards Institution: Warszawa, Poland, 2005.

22. Dołżycki, B. Instrukcja Projektowania i Wbudowania Mieszanek Mineralno-Cementowo-Emulsyjnych (MCE); Deneralna Dyrekacja Dróg Krajowych i Autostrad, Warszawa, Poland, 12 maj 2019. Available online: https://www.gddkia.gov.pl/frontend/web/userfiles/articles/d/dokumenty-techniczne_8162/ Wytyczne_RID/Recykling/Za\%C5\%82\%C4\%85cznik\%209.4.2.pdf (accessed on 28 November 2020).

23. Bituminous Mixtures. Test Methods. In Specimen Preparation by Impact Compactor; PN-EN 12697-30; Polish Standards Institution: Warszawa, Poland, 2008.

24. Bituminous Mixtures. Test Methods. In Determination of the Maximum Density; PN-EN 12697-5; Polish Standards Institution: Warszawa, Poland, 2008.

25. Bituminous Mixtures. Test Methods. In Determination of Bulk Density of Bituminous Specimens; PN-EN 12697-6; Polish Standards Institution: Warszawa, Poland, 2008.

26. Bituminous Mixtures. Test Methods. In Determination of the Indirect Tensile Strength of Bituminous Specimens; PN-EN 12697-23; Polish Standards Institution: Warszawa, Poland, 2009.

27. Unbound and Hydraulically Bound Mixtures. Test Method for Determination of the Compressive Strength of Hydraulically Bound Mixtures; PN-EN 13286-41; Polish Standards Institution: Warszawa, Poland, 2005.

28. Drogi Samochodowe. In Oznaczanie Modułu Odkształcenia Nawierzchni Podatnych i Podłoża Przez Obciązenie Ptyta; BN-64/8931-02; Wydawnictwo Normalizacyjne Alfa: Warszawa, Poland, 1965.

29. Drogi Samochodowe. In Roboty Ziemne; Wymagania i Badania PN-S 02205; Polski Komitet Normalizacyjny: Warszawa, Poland, 1998.

30. Unbound and Hydraulically Bound Mixtures. Method for the Manufacture of Test Specimens of Hydraulically Bound Mixtures Using Proctor Equipment or Vibrating Table Compaction; PN-EN 13286-50; Polish Standards Institution: Warszawa, Poland, 2007.

Publisher's Note: MDPI stays neutral with regard to jurisdictional claims in published maps and institutional affiliations.

(C) 2020 by the authors. Licensee MDPI, Basel, Switzerland. This article is an open access article distributed under the terms and conditions of the Creative Commons Attribution (CC BY) license (http://creativecommons.org/licenses/by/4.0/). 